\title{
The Speargrass (Imperata cylindrica (L) Beauv.) Menace in Ghana: Incidence, Farmer Perceptions and Control Practices in the Forest and Forest-Savanna Transition Agro-ecological Zones of Ghana
}

\author{
G. E.-K. Bolfrey-Arku* ${ }^{*}$, O. U. Onokpise ${ }^{2}$, A. G. Carson ${ }^{3}$, D. G. Shilling ${ }^{4}$ and C. C. Coultas ${ }^{2}$ \\ ${ }^{\prime}$ CSIR-Crops Research Institute, P. O. Box 3785, Kumasi, Ghana \\ ${ }^{2}$ Florida A \& M University, Tallahassee, Fl, USA \\ ${ }^{3}$ School of Agriculture, University of Cape Coast, Cape Coast, Ghana \\ ${ }^{4}$ University of Georgia, Atlanta, USA \\ *Corresponding author
}

\begin{abstract}
Surveys to determine farmers' practices, perceptions and the incidence of speargrass were conducted in the forest and forest-savanna transition zones of Ghana in 1996 and 2000. Mean farm size was 1.2 ha, fallow and cropping length was 4.7 and 4.5 years, respectively, with a mean cropping intensity factor (CIF) of 49\%. Speargrass had been present in the area for over 40 years and was perceived as the most noxious weed. Eighty- six percent of fields that relied on slash-burn method of land preparation had severe speargrass infestation. Infestations $>50 \%$ cover, mean density of 33 plants $m^{-2}$ and shoot height range of 15-300 cm were observed on $60 \%$ of the fields. Fifty-one percent of farmers reported of inadequate level of control with current control practices. Glyphosate was applied on fields with $>50 \%$ speargrass cover. Speargrass becomes a problem after 3 years continuous cropping from fallow and, under severe infestation, most farmers abandon fields to natural fallow. A dense regrowth of Chromolaena odorata is indicative of a speargrass-suppressed field. Follow-up weed control could be 3-6 times/season depending on initial land preparation, type of crop and/or level of infestation. Cost of weed control was 20-60\% higher on speargrass-infested field (\$71/weeding/ha) than on other fields, and weeding may take 20-25 mandays/ha. Farmers perceived average yield losses of $30-80 \%$ ha $^{-1}$ due to speargrass interference, implying a national average crop loss hat of \$31-\$84, \$155-\$414 and \$272-\$727 for maize, cassava and yam systems, respectively. Reductions in food quality due to the piercing nature of the rhizomes was also paramount.
\end{abstract}

\section{Introduction}

Speargrass (Imperata cylindrica L. Beauv.) is one of the most dominant and noxious weeds in agricultural and non-agricultural fields in West Africa. It is ranked as the world's seventh worst weed (Holm et al., 1977). The persistent and aggressive rhizomes of speargrass are the main mechanism of spread, and, coupled with their resilience, speargrass is very difficult to control. The weed has, therefore, received extensive research attention because of its agricultural, economic and social importance in a wide variety of habitats, climates and cultures.

Chikoye et al. (1999) report coverage range of $9-97 \%$ of farmers' fields in West Africa. In Nigeria, it is reported to have the potential to invade 260 million hectares of land and negatively affect nearly 80 million people residing in intensively cultivated areas of the moist savanna and humid forest zones (Chikoye et al., 1999). Speargrass offers serious competition to cereals, grain legumes, vegetables, and root and tuber crops. The growing rhizomes pierce through and cause 
physical injury to groundnut, and root and tuber crops, predisposing them to attack by disease pathogens. Boonitee \& Ritdhit (1984) also reported the allelopathic effect of speargrass on other crops.

In Ghana, the forest, forest-savanna-transition and coastal savanna zones, which are intensively cropped to cereals, legumes, vegetables, root and tuber crops are prone to frequent burning, which, according to Anoka (1995), contributes to the dominance of the weed. The inability of the Ghanaian small-scale farmer to effectively manage speargrass has led to its increased spread and, hence, a major constraint to food production in those areas. Though it is generally believed that speargrass abounds in these ecological zones, there is a dearth of documented information on the incidence and severity of infestation, management systems and farmers' perception of the weed in Ghana.

According to Chikoye et al. (1999), the development of a comprehensive manage-ment strategy for speargrass and other weeds should be a priority research because the weed threatens the livelihood of over 200 million people in West Africa. Since agricultural practices can result in declines or increases in the occurrence of weed species, it is important to have information on weeds perceived to be noxious, and how their control affects costs of production and crop yields in the various ecological zones. In Ghana, speargrass has become a serious problem in the forest, transition and coastal savanna areas, where human population pressure on land has prevented the re-establishment of the forest vegetation. The need for maintaining the soil fertility to prevent clearing of virgin land with the resultant invasion by noxious weeds, including speargrass for that matter, has become very necessary. Knowledge of weed control practices employed by farmers is vital in developing control measures for a country where most of the farmers are peasants.

The study was, therefore, conducted to characterize the cropping systems of speargrass infested areas, determine the incidence and spread of speargrass, and document farmers' perceptions of speargrass in relation to other weeds. The study also investigated farmers' existing speargrass management interventions and quantification of yield losses attributable to the weed.

\section{Study areas}

\section{Materials and methods}

Surveys were conducted in 1996 and 2000 in the Ashanti and Brong Ahafo regions of Ghana in the forest and forest-savanna transition ecological zones. The areas were selected on the basis of the importance of the weed problem. The Wenchi, Nkoranza and Techiman districts (Brong Ahafo Region), and Ejura-Sekyidumase District (Ashanti Region), all in the forest-savanna transition zone, and the Sekyere West District (Ashanti Region) in the forest zone were selected for the study. The districts and their locations are presented in Fig. 1. All the areas have the bimodal rainfall pattern, which allows for two cropping seasons within a year, and are located between latitudes $7^{0}$ and $8^{0} \mathrm{~N}$.

\section{Data collection}

The random sampling procedure was used to select 84 farmers, 21 from each of the four districts. The selection was made from a compilation of farmers with fields infested with spearglass. The farmer sample consisted of $77 \%$ males and $23 \%$ females with age range of 20-60 years. For each farmer, one field was surveyed. The data was collected randomly through individual, household and group interviews, with some of the interviews conducted on the field. Weed assessment was through field sampling. Five square quadrats of $1 \mathrm{~m}^{2}$ were randomly placed in surveyed fields and the number of speargrass shoots/quadrat recorded. Speargrass percentage cover was visually estimated based on discrete classes as $0-25 \%$ (low), 26-50\% (moderate), 51$75 \%$ (heavy) and $>75 \%$ (very heavy). Noxious weeds were assigned on a scale of $1-4$, where 1 
was the most noxious and 4 the least noxious. The data was analyzed with SPSS 8.0 for Windows. Cropping intensity factor (CIF), an indicator of the ratio between length of cropping and fallow, was computed as:

$$
\mathrm{CIF}=\{\mathrm{C} /(\mathrm{C}+\mathrm{F})\} \times 100
$$

where $\mathrm{C}=$ length of cropping and $\mathrm{F}=$ fallow period.

\section{Results and discussion}

\section{Farmer and cropping characteristics}

Farmers relied mainly on manual methods of weed control supplied mostly by family labour. Eighty-three percent of the farmers have farms of up to 2 ha in size, with a mean of 1.2 ha. Intercropping was prevalent because most farmers rented the land and needed security for payment. Yam/maize/cassava mixtures alone was practiced on $24 \%$ of the fields in all the districts (Table 1), consistent with reports on cropping systems from other studies in Ghana (Marfo et al., 1994; Anchirinah et al., 1996). Com-binations of 2-6 crops in speargrass dominated fields in West Africa have also been reported (Holm et al., 1977; Chikoye et al., 2000). Sixty percent of the fields had been in fallow for at most 5 years, while $69 \%$ had been continuously cropped for 3 or more years. The low CIF of $43 \%$ and $47 \%$ in the Sekyere West or Ejura districts, respectively, as presented in Table 2, implies that certain parts of the area were yet to be intensively cropped. This could probably be due to availability of land, hence, the over 5 -year fallow periods. However, the fallow period in the Techiman and Wenchi districts conform to the average fallow period of 3-5 years reported by Anchirinah et al. (1996).

TABLE 1

Distribution of cropping systems in selected districts of the forest and forest-savanna transition zones of Ghana

$\begin{array}{lr}\text { Cropping systems } & \text { Percent of fields* } \\ \text { Yam } & 1.3 \\ \text { Maize } & 6.4 \\ \text { Cassava } & 6.4 \\ \text { Vegetables } & 10.3 \\ \text { Yam/Maize } & 5.1 \\ \text { Yam/Cassava } & 6.4 \\ \text { Maize/Cassava } & 2.6 \\ \text { Maize/Millet } & 1.3 \\ \text { Maize/Cassava/Groundnut } & 2.6 \\ \text { Maize/Cassava/Millet } & 1.3 \\ \text { Yam/Maize/Vegetable } & 1.3 \\ \text { Yam/Millet/Vegetable } & 1.3 \\ \text { Yam/Maize/Cassava } & 24.4 \\ \text { Maize/Cassava/Vegetable/Cowpea } & 2.6 \\ \text { Yam/Maize/Cassava/Groundnut } & 3.8 \\ \text { Yam/Millet/Groundnut/Cowpea } & 1.3 \\ \text { Yam/Maize/Cassava/Vegetable/Cowpea } & 5.1 \\ & \\ \text { * Fraction of total fields surveyed expressed as percentage } & \end{array}$

It was observed that fields abandoned due to speargrass invasion were returned to only when there was a dense growth of Chromolaena odorata to suppress the speargrass. This observation supports the $49 \%$ mean CIF (Table 2). The high CIF of $67.4 \%$ in the Techiman District could be due to the presence of the major market at Techiman that links the northern and southern parts of 
the country. The market, as well as the rapidly expanding population, exerts high pressure on the land. Boserup (1987) hypothesized that farming systems in many African countries were determined by population growth, which influences agricultural change, rather than agricultural production determining population growth. The evolutionary path is as follows: forest fallow, bush fallow, short fallow, annual cultivation and multiple cropping, with the successive stages associated with more intense use of the land through higher levels of technology, labour and capital investment. Similar reasons can be adduced for Wenchi, which is $29 \mathrm{~km}$ north of Techiman.

TABLE 2

Duration of fallow, cropping and cropping intensity in the districts

\begin{tabular}{lccc} 
District & Fallow length & $\begin{array}{c}\text { Cropping length } \\
\text { (years } \pm \text { SE) }\end{array}$ & $\begin{array}{c}\text { Cropping intensity } \\
(\%)\end{array}$ \\
Wenchi & \multicolumn{2}{c}{} & \\
Techiman & $3.88 \pm 0.35$ & $4.25 \pm 0.46$ & 52.30 \\
Ejura-Sekyedumase & $3.20 \pm 0.86$ & $6.60 \pm 1.47$ & 67.35 \\
Sekyere West & $5.33 \pm 0.35$ & $4.10 \pm 0.65$ & 43.50 \\
Mean & $5.52 \pm 0.30$ & $4.90 \pm 0.61$ & 47.02 \\
& $4.72 \pm 0.21$ & $4.52 \pm 0.32$ & 48.92
\end{tabular}

Duration and degree of speargrass infestation and distribution

Speargrass was reported by $40 \%$ of farmers to have been present from 20 to over 60 years and seemed to have been present in the forest-savanna transition zone longer than in the forest zone (Table 3). Some farmers believed that the shorter fallows of less than 10 years and more continuous cropping, which lead to loss of tree cover have also contributed to the presence and spread of speargrass in the forest because it cannot survive very well under shade, a fact established by Ivens (1980). The increasing spread and incidence may also be attributed to the activities of timber firms and charcoal producers which are very rife and thriving businesses in the study areas. Tjitrosoedirdjo (1993) reported repeated logging and bushfire as primary contributors to succession, leading to speargrass dominance. It is also possible that the use of speargrass shoots as roofing thatch and the movement of soil for develop-mental purposes, such as road and house construction, have also contributed, to its rapid spread.

TABLE 3

Farmer perception of duration of speargrass by districts

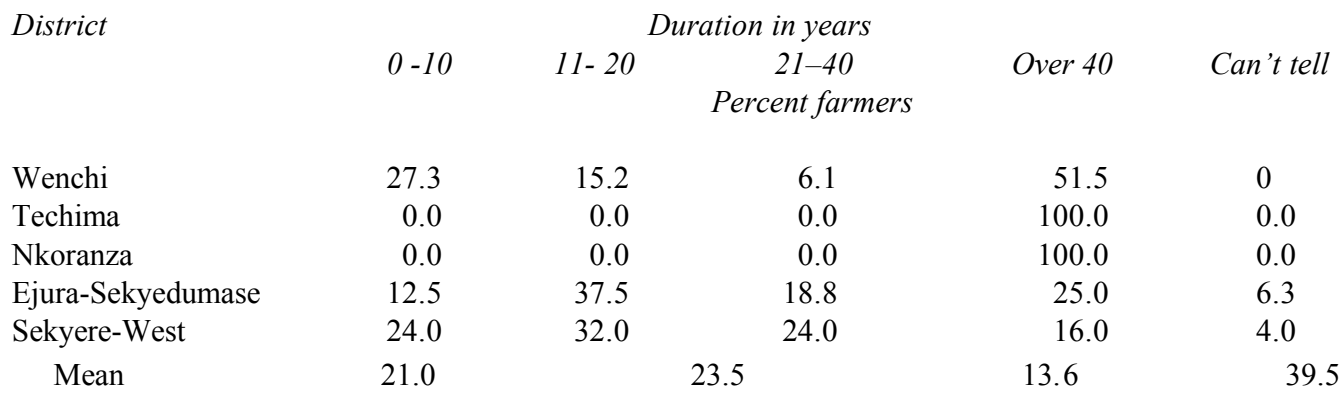

Speargrass was present in $94 \%$ of the fields with higher incidence on the fields that were subjected to slash and burn (86\%) as a way of land preparation. Bushfire has been reported by Bryson \& Carter (1993) and Friday et al. (1999) to induce flowering and seeding, stimulate 
rhizome sprouting, reduce competition from other plants, and create openings for speargrass seedling establish-ment. Across zones, $60.2 \%$ of fields had heavy speargrass infestations ( $>$ $50 \%$ ), while $39.7 \%$ showed moderate infestations of less than $50 \%$, with mean density of 33 plants $\mathrm{m}^{-2}$ and shoot height of 15-300 $\mathrm{cm}$ (Table 4). The weed was found on farmlands, along roads, at backyards, disturbed lands, such as sand winning sites, and on all soil types whether well or poorly drained. Manyong et al. (1996) reported speargrass occur-rence as heterogeneous with respect to climate, vegetation, soils, farmer resources and infrastructure.

TABLE 4

Speargrass infestation and density across surveyed districts

$\begin{array}{lllll}\begin{array}{l}\text { Infestation } \\ \text { Percent } \\ \text { cover }\end{array} & \text { Score } & \begin{array}{c}\text { Percent } \\ \text { fields }^{*}\end{array} & \begin{array}{l}\text { Density } \\ \text { (plants/ } \\ \mathrm{m}^{2} \text { ) }\end{array} & \begin{array}{l}\text { Percent } \\ \text { fields }\end{array} \\ \mathrm{d} \cdot 50 & \text { moderate } & 39.1 & 20 & 56.7 \\ 51-80 & \text { heavy } & 30.1 & 21-40 & 26.7 \\ >80 & \text { severe } & 30.1 & 41-100 & 10 \\ & & & >100 & 6.7\end{array}$

- $\quad=$ Fraction of total fields surveyed expressed as percentage

Generally, the incidence and severity of speargrass infestation increased with length of cropping (Table 5). The incidence was $4.1 \%$ on fields cropped from fallow and $34.2 \%$ on fields cropped for over 4 years. Of the fields with speargrass cover of $>80 \%, 40.9 \%$ of them had been cropped for over 4 years, $27.3 \%$ had been cropped for $3-4$ years and $18.2 \%$ for up to 2 years. At Techiman, $83 \%$ of the fields surveyed had very severe speargrass infestations $(>80 \%$ cover) compared to about $30 \%$ in the other districts (Fig. 2). The heavy infestation at Techiman could be due to the high cropping intensity. It is also possible that shallow cultivation performed in the rainy season, mostly with the hoe which usually breaks rhizomes into small pieces, may inadvertently eliminate apical dominance resulting in increased sprouting of buds and subsequent shoot growth.

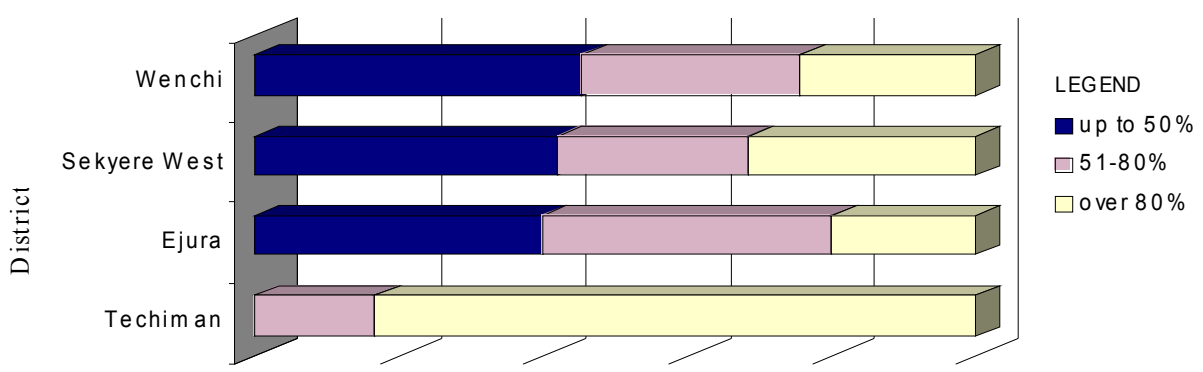

Fig. 2. Percent speargrass infestation by district

Farmer perception of speargrass and other weeds

The weed has several local names but 'eto' or 'seregogoro' was the most common because it is the language of the dominant tribe (Twi) in the surveyed area. These names show how it is perceived. For example 'eto' means 'you will meet me' or 'always around' while 'seregogoro' 
implies 'pierces like needle' alluding to the piercing nature of the emerging rhizomes. Speargrass was ranked as the most noxious weed by $80 \%$ of the farmers across the ecological zones (Table 6). Interestingly, this perception was not gender dependent. The reasons assigned for the ranking included difficulty to control manually (requiring much labour), competitiveness and the piercing nature of emerging rhizomes on crop and humans. Tubers of cassava, yam and sweet potato and the pods of groundnut have been reported to be pierced right through by the growing rhizomes and emerging shoots disposing them to secondary infection by disease pathogens (Anoka, 1995; Chikoye et al., 2000). The farmers also intimated that speargrass limited field size and increased the occurrence of bushfires.

TABLE 6

Farmers' ranking of speargrass among other weeds by gender and districts

$\begin{array}{lcccc}\text { Character } & \text { Worst weed } & \begin{array}{c}\text { Percent farmers } \\ \text { Worse weed }\end{array} & \text { Bad weed } & \text { Unimportant } \\ \text { Sex } & & & & \\ \text { Male } & 81.3 & 15.6 & 1.6 & 1.6 \\ \text { Female } & 78.9 & 15.8 & 5.3 & 0.0 \\ \text { District } & & & & \\ \text { Wenchi } & 69.7 & 27.3 & 3.0 & 0.0 \\ \text { Techiman } & 100.0 & 0.0 & 0.0 & 0.0 \\ \text { Ejura-Sekyedumase } & 93.8 & 6.3 & 0.0 & 0.0 \\ \text { Sekyere West } & 80.0 & 12.0 & 4.0 & 4.0 \\ \text { Mean } & 80.2 & 16.0 & 2.5 & 1.2\end{array}$

Sixty-seven percent of the farmers also mentioned that speargrass first becomes a problem after 3 years cropping from fallow (Table 7). Across ecological zones Cyperus rotundus, Euphorbia heterophylla, Commelina spp., Centrosema pubescens, Chromolaena odorata and Rottboellia cochinchinensis were also listed as troublesome weeds. E. heterophylla has been reported as very competitive in yam, maize, cowpea and soybean (Akobundu et al., 1987, 1988; Anchirinah et al., 1996).

TABLE 7

Farmer perception of period after which speargrass becomes a problem following cropping by districts

\begin{tabular}{|c|c|c|c|}
\hline \multirow[t]{2}{*}{ District } & \multicolumn{3}{|c|}{ Percent farmers } \\
\hline & First 3 years & After 4 years & Can't tell \\
\hline Wenchi & 60.6 & 24.2 & 15.2 \\
\hline Techiman & 42.9 & 42.9 & 14.3 \\
\hline Ejura-Sekyedumase & 62.5 & 31.3 & 6.3 \\
\hline Sekyere West & 84.0 & 8.0 & 8.0 \\
\hline Mean & & 66.7 & 2.2 \\
\hline
\end{tabular}

Some uses of speargrass mentioned by the farmers were roofing material by $87.8 \%$ of farmers, medicinal (8.7\%) and livestock fodder (2.4\%). Townson (1991) and Chikoye et al. (2000) have also reported similar uses elsewhere. The use of speargrass for soil erosion control (Suryatna et $a l ., 1980)$ was, however, not mentioned by any of the farmers.

Land preparation and follow-up weed control 
Slash-burn was the predominant form of land preparation, practiced by $86.7 \%$ of the farmers. Out of these, $77 \%$ follow it up with hoeing, 17\% use herbicide (glyphosate), while 6\% plough with the tractor. For those who did not burn at land preparation, $70 \%$ used the hoe, $10 \%$ applied herbicide and $20 \%$ used the tractor to plough. Herbicides were mainly used at EjuraSekyedumase and Sekyere West districts. Of those who use herbicide (glyphosate), $86 \%$ apply on fields that had more than $50 \%$ speargrass infestation. The extensive promotion through demonstrations of Round-up (glyphosate) dry sachets and the liquid formulation for zero-tillage maize production by the CSIR-Crops Research Institute may explain the high use of glyphosate in those areas.

Follow-up weed control mainly with the hoe or cutlass could be 3-6 times per season depending on type of crop and level of infestation. It usually takes about 20-25 man days ha ${ }^{-1}$. Weeding twice in a speargrass infested maize and cowpea field consumed 54\% of total farm labour (IITA, 1977), while four weedings were required to prevent economic maize yield reduction in the derived savanna (Akobundu et al., 2000). Sixty-four percent of farmers usually do the first follow-up weeding at 3-4 weeks, $21 \%$ at 2 weeks, $12 \%$ as and when necessary, and $4 \%$ at 6 weeks after planting. The cost of weeding one hectare of speargrass infested field ranges from \$18-\$33 compared to \$15-\$23 on non-infested field.

Fifty-one percent of the farmers reported of inadequate level of control with current control practices. Under severe infestation, most of the farmers abandon fields to natural fallow while $13 \%$ use glyphosate because they could not afford to fallow. Akobundu et al. (1999) also reported that abandoning land to natural fallow is the traditional way of fighting the weed buildup in Nigeria. The abandoned fields are, however, returned to when there is a dense regrowth of C. odorata, indicative of speargrass suppres-sion. Generally, C. odorata has been observed to commonly follow speargrass in vegetation succession (Eussen \& Wirjahardja. 1973). None of the farmers mentioned the use of cover crop fallow for reclaiming speargrass infested fields (Versteeg et al., 1998).

\section{Yield reduction attributable to speargrass}

Farmers estimated crop yield loss due to speargrass to be between $30 \%$ and $80 \%$ when speargrass is not controlled on time or appropriately. Forty-six percent of the farmers reported losses of greater than $80 \%, 43 \%$ of them pegged it at $31-80 \%$ while $11 \%$ of them estimated it at less than $30 \%$. In maize or its associations, $51-80 \%$ yield could be lost to speargrass (Table 8 ). For yam or cassava based systems, yield losses due to late weeding of speargrass could range from $31 \%$ to over $80 \%$. Koch et al. (1990) have reported maize grain yield reduction up to $100 \%$ and over $90 \%$ in maize-cassava intercrop. Most farmers had, however, observed that very good crop yields are realized on relatively fertile speargrass infested fields if there is good and timely control. They believed the rhizomes improve infiltration of water to the soil by opening up the pores. Similarly, Soepardi (1980) indicated that speargrass improves soil physical properties, which allow free access to water; and fertility by extracting nutrients from deep in the soil profile.

TABLE 8

Farmer estimated yield loss in cropping systems due to inadequate or untimely control of speargrass by cropping systems

$\begin{array}{lrrrr}\text { Cropping systems } & <30 & 31-50 & 51-80 & >80 \\ \text { Yam } & - & - & - & 7.7 \\ \text { Cassava } & 33.3 & 16.7 & - & 15.4 \\ \text { Vegetables } & - & 16.7 & 16.7 & -\end{array}$




$\begin{array}{lrrrr}\text { Yam/Maize } & - & - & - & 7.7 \\ \text { Yam/Cassava } & - & 33.3 & 16.7 & 7.7 \\ \text { Maize/Millet } & - & - & - & 7.7 \\ \text { Maize/Cassava/Groundnut } & - & - & 16.7 & 23.1 \\ \text { Yam/Maize/Vegetable } & - & - & - & 7.7 \\ \text { Yam/Millet/Vegetable } & - & 16.7 & - & - \\ \text { Yam/Maize/Cassava } & 66.7 & - & 16.7 & 23.1 \\ \text { Maize/Cassava/Vegetable/Cowpea } & - & - & - & 7.7 \\ \text { Yam/Maize/Cassava/Groundnut } & - & 16.7 & - & 15.4 \\ \text { Yam/Millet/Groundnut/Cowpea } & - & - & 16.7 & - \\ \text { Yam/Maize/Vegetable/Cowpea } & - & - & 16.7 & -\end{array}$

\section{Conclusion}

Impact and implication for sustainable food production

The dominance of speargrass in the forest-savanna transition zone and the forest zone of the Sekyere West District could be attributabble to the slash-burn method of land preparation, charcoal production and logging for timber. Also, speargrass becomes a problem after continuous cropping for over 3 years. Speargrass is suppressed and loses its status as a major weed when cultivated lands are put under long natural fallows $\quad(\geq 10$ years) This study and others (Owusu-Bennoah, 1997; Anchirinah et al., 2000) give a strong evidence of accelerated change in land use systems which is preventing the re-establishment of the forest vegetation as a result of increased population growth with its subsequent development.

The estimated direct yield loss associated with speargrass interference, based on national production figures from 1993 to 2002 (MOFA, 2003), when translated into monetary terms, implies a national average loss of \$31-\$84, \$272-\$727 and \$155-\$414 per hectare for maize, yam and cassava systems, respectively. In addition, farmers have to contend with reductions in food quality due to the piercing nature of the emerging rhizomes. This makes control of speargrass very important to ensure the sustainability of the forest and forest-savanna transition ecologies since the dependent communities derive about $60 \%$ of their livelihood directly or indirectly from these ecologies (Cobbinah, 2000).

Thus, the need for the provision of environmentally sustainable alternatives to existing speargrass and other weed control methods adopted by the farmers in Ghana to push the country to the middle level income status soonest is very imperative. However, any proposed interventions should aim at reclaiming speargrass infested fields and improve soil fertility to minimize deforestation in these areas, which form a substantial proportion of the "bread basket' zones of Ghana.

\section{Acknowledgement}

Financial support for this study was provided by USAID-HBCU-CRP and USDA/FAS/RSED grants with logistic support from CSIR-Crop Research Institute, Ghana. The authors are grateful to Mr A. Y. Kwarteng, Mr Offe Bediako, Dr K. A. Marfo, Mr V. M. Anchirinah and Ms J. Hallegoah, for their help in data collection and analyses. They are also grateful to the staff of the Ministry of Food and Agriculture in the survey areas.

\section{References}

Akobundu I. O. (1987). Weed Science in the Tropics: Principles and Practices. John Wiley \& Sons, Inc., Chichester, UK. pp. 337-367.

Akobundu I. O. and Agyakwa C. W. (1988). A handbook of West African weeds, 2nd edn. International Institute of Tropical Agriculture, Ibadan, Nigeria. 564 pp. 
Akobundu I. O., Ekeleme F. and Chikoye D. (1999). The influence of fallow management system and frequency of cropping on weed growth and crop yield. Weed Res. 39: 241-256.

Akobundu I. O., Udensi E. U. and Chikoye D. (2000). Velvet bean (Mucuna spp.) suppresses speargrass (Imperata cylindrica (L) Raeuschel) and increases maize yield. Int. J. Pest Mgmt 46:103-108.

Anchirinah V. M., Addison M., Dapaah H. K. and Yiridoe E. K. (2000). Prospects of using improved intermediate means of transport in Ghanaian agriculture: a survey. J. sustain. Agric. 17(2/3): 145-168.

Anchirinah V., Ojiha D., Owusu-Sekyere R., Ramnanan N. and Zhou S. (1996). Production and marketing of yams in the forest/savanna transition zone of Ghana. International Centre for Development Oriented Research in Agriculture (ICRA). Working Document Series 53: 38-39, 67: 68.

Anoka A. (1995). Phenology of speargrass [Imperata cylindrica (L.) Räeuschel variety Africana (Andeass) C. E. Hubbard] and the contributions of bush-fire, cultivation and nitrogen fertilizer to its persistence in arable lands. (PhD Thesis.). University of Reading in conjunction with IITA. $187 \mathrm{pp}$.

Boonitee A. and Ritdhit (1984). Allelopathic effects of some weeds on mungbean plants (Vigna radiata). Proceedings of the 1st Tropical Weed Science Conference 2: 401-406. Hat Yai, Songkhia, Thailand.

Boserup E. (1987). Agricultural growth and population change. In The New Palgrave: A Dictionary of Economics. (J. Eatwell, M. Milgate and P. Newman, ed.). Macmillan, London and Basingstoke.

Bryson C. T. and Carter R. (1993). Congograss, Imperata cylindrica, in the United States. Weed Technol. 7: 10051009.

Chikoye D., Ekeleme F. and Ambe J. T. (1999). Survey of distribution and farmers' perceptions of speargrass (Imperata cylindrica (L.) Räeuschel) in cassava-based systems in West Africa. Int. J. Pest Mgmt 45(4): 305-311.

Chikoye D., Manyong V. M. and Ekeleme F. (2000). Characteristics of speargrass (Imperata cylindrica) dominated fields in West Africa: crops, soil properties, farmer perceptions and management strategies. Crop Prot. 19: 481487.

Cobbinah J. H. (2000). Lumbering and agriculture on forest degradation in the forest belt of Ghana. In Managing our environment: CSIR's Involvement and Contribution. Proceedings of CSIR-RSA National Symposia, Kumasi, pp 41-45. Ghana.

Eussen J. H. H. and Wirjahardja S. (1973). Studies of an alang-alang (Imperata cylindrica (L.) Beauv.) vegetation. BIOTROP Bull. 6: 1-24.

Friday K. S., Drilling M. E. and Garrity D. P. (1999). Imperata grassland rehabilitation using agroforestry and assisted natural regeneration. ICRAF, Southeast Asia Regional Center, Bogor, Indonesia.

Holm L. R., Pluncknett D. L., Pancho J. V. and Herberger J. P. (1977). Imperata cylindrica (L.) Beauv. In The world's worst weeds: Distribution and biology. pp. 62-71. University Press of Hawaii, Honolulu, USA.

IITA (1977). Annual Report 1987. International Institute of Tropical Agriculture, Ibadan, Nigeria. 37 pp.

Ivens G. L. (1980). Imperata cylindrica (L.) Beauv. in West Africa agriculture. BIOTROP Spec. Publ. 5:149-156.

Koch W., Grossmann F., Weber A., Lutzeyer H. J. and Akobundu I. O. (1990). Weeds as components of maize/cassava cropping systems. In Standorttgemasse landwirtschraft in West Africa, pp. 283-298. Universitaet Hohenheim, Stuttgart, Germany.

Manyong V. M., Smith J., Weber G. K., Jagtap S. S and Oyewole B. (1996). Macro characterization of agricultural systems in West Africa: an overview. Resour. Crop Mangmt Monog. 21: 33-40. International Institute of Tropical Agriculture, Ibadan, Nigeria.

Marfo K. A., Ntow A., Ohemeng-Dapaah S. and Osei-Yeboah S. (1994). Socio-economic studies of farming systems in Ghana. Report prepared for the National Agricultural Extension Project (Draft). MOFA, Accra.

MOFA (2003). Annual Report 2003. Statistics, Research and Information Directorate, Ministry of Food and Agriculture, Accra, Ghana.

Owusu-Benoah H. E. (1997). Soils. In Environment, Biodiversity, and Agricultural Change in West Africa: Perspectives from Ghana. (K. G. Edem and I. U. Juta, ed.). United Nations University Press, Tokyo-New YorkParis. 157 pp.

Soiepardi G. (1980). Alang-alang and soil fertility. BIOTROP Spec. Publ. 5: 57-69.

Suryatna E. S. and McIntosh J.L. (1980). Food crops production and control of Imperata cylindrica in small grains. BIOTROP Spec. Publ. 5: 135-147.

Tjitrosoedirdjo S. (1993). Rehabilitation of Imperata cylindrica grassland in Indonesia (A Review). BIOTROP Spec. Publ. 50.

Townson J. K. (1991). Imperata cylindrica and its control. Weed Abstr. 40: 457-468.

Versteeg M. N., Amadji F., Eteka A., Gogan A. and Koudokpon V. (1998). Farmers' adoptability of mucuna

fallowing and agroforestry technologies in the Coastal Savanna of Benin. Agric. Syst. 56(3): 269-287. 